\title{
$\square$
}

\section{A Primer on the Mortgage Market and Mortgage Finance}

\author{
Daniel J. McDonald and Daniel L. Thornton
}

\begin{abstract}
This article is a primer on mortgage finance. It discusses the basics of the mortgage market and mortgage finance. In so doing, it provides useful information that can aid individuals in making better mortgage finance decisions. The discussion and the tools are presented within the context of mortgage finance; however, these same principles and tools can be applied to a wide range of financial decisions. (JEL G0, G1)
\end{abstract}

Federal Reserve Bank of St. Louis Review, January/February 2008, 90(1), pp. 31-45.

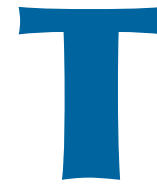

he United States was in the midst of a residential real estate boom from 1996 to 2005, and the U.S. Census Bureau reports for that period show that homeownership-the percentage of home-owning households-increased from 65.4 percent to 68.9 percent. During this decade, the Standard \& Poor/Case-Shiller Home Price Index rose at a compounded annual rate of 8.5 percent per year, more than four times faster than the rate of inflation. Growth in home prices was particularly strong during the period 2000-05, when home prices rose at an annual rate of 11.4 percent. However, since the first quarter of 2006, house price growth has slowed dramatically; and, in the first quarter of 2007, prices fell for the first time since 1991. These price declines, combined with higher interest rates, have led to increased mortgage delinquency, especially in the subprime mortgage market. Federal Reserve Chairman Bernanke reported recently that the "rate of serious delinquencies for subprime mortgages with adjustable interest rates...has risen to about 12 percent, roughly double the recent low seen in mid-2005."1 On news that the subprime woes may spill over to borrowers with good credit, rates on mortgage-backed securities rose, while rates on risk-free Treasury bills declined dramatically. ${ }^{2}$

Against this backdrop, this article serves as a primer on mortgage finance. It discusses the basics of the mortgage market and mortgage finance, providing useful information that can aid individuals in making better mortgage finance decisions. Although the discussion and the tools are presented within the context of mortgage finance, these same principles and tools can be applied to a wide range of financial decisions.

\section{ETYMOLOGY}

The term mortgage comes from the Old French, and literally means "death vow." This refers not to the death of the borrower, but to the "death" of the loan. This is because mortgages, like many other types of loans, have a fixed term to maturity - that is, a date at which the loan is to be fully repaid. Today, mortgages are paid in

\footnotetext{
1 Bernanke (2007).

2 For a discussion of the development of the subprime mortgage market, see Chomsisengphet and Pennington-Cross (2006).
}

Daniel J. McDonald is a research analyst and Daniel L. Thornton is a vice president and economic adviser at the Federal Reserve Bank of St. Louis.

(C) 2008, The Federal Reserve Bank of St. Louis. Articles may be reprinted, reproduced, published, distributed, displayed, and transmitted in their entirety if copyright notice, author name(s), and full citation are included. Abstracts, synopses, and other derivative works may be made only with prior written permission of the Federal Reserve Bank of St. Louis. 
installments (most often, monthly), so that the loan is repaid over time rather than as a lump sum on the maturity date. The word for this repayment is amortization, which derives from the Middle English for "kill." It refers not to the borrower's murder, but to "killing off" the mortgage by paying it down over time. The morbid etymology of these real estate terms must have some subliminal impact on potential borrowers, as many continue to find the process of getting a mortgage unnerving; however, a mortgage is nothing to be afraid of, as we hope to demonstrate in the remainder of this article.

\section{MORTGAGE BASICS}

"Mortgage" is nothing more than the name given to a particular type of loan; in this case, a real estate loan. ${ }^{3}$ Like any other loan, it is really an IOU-that is, a promise to repay a sum of money received today at some future time. Although the names of loans change for a variety of reasons, they all have the same basic characteristics: the loan amount, the loan term, the schedule for repayment, and the contract interest rate.

The amount of a loan is just that-a sum of money that the borrower receives upon signing the loan agreement. The term (or maturity) of the loan is the length of time over which the loan amount is to be repaid. The schedule for repayment simply states how the loan is to be repaid. Loans can be repaid in installments over the term of the mortgage, in a lump sum at the terminal date of the contract, or in some combination of installments and a final lump sum payment. In the case of mortgages, auto loans, and other consumer loans, the convention is that the loan is repaid in fixed periodic payments, typically monthly. The contract interest rate is the interest rate that the borrower pays the lender in exchange for having the money today.

There are two risks associated with lending. The first, called default risk, is the possibility

\footnotetext{
3 Legally speaking, the loan takes the form of a note and the mortgage per se is the agreement that secures the note by pledging the real estate as collateral. It is commonplace to refer to both the note and mortgage agreement that secures the note as the "mortgage."
}

that the borrower fails to repay the loan. The second, called market risk, arises when interest rates change over time. If market interest rates rise after the lender has offered a mortgage contract, not only will the lender earn less interest than he would have had he waited and lent at the higher interest rate, but the market value of the investment will decline. Of course, the reverse is also true: If market interest rates fall, the lender will earn more interest than if he waited and the market value of his investment will increase. The risk is due to the fact that it is very difficult to predict whether interest rates will rise or fall. The lender also risks losing the higher interest he would earn if the individual decides to refinance the loan at a lower rate.

The prospect of default has led societies to develop laws and mechanisms to protect the lender. One of these is collateral-an asset owned by the borrower that becomes the lender's in the event that the borrower fails to repay the loan. In the case of mortgages, the collateral is nearly always the property being purchased. Loan agreements may also contain a variety of restrictions. Some of these are intended to protect the lender, while others protect the borrower. For example, in the past, many mortgages were "assumable," meaning that if the borrower sold the house, the mortgage could be assumed or transferred to the new owner. This hurt lenders when interest rates rose because the new owner could get a "belowmarket interest rate" by assuming the previous mortgage. Today, mortgages are typically not assumable. There was also a time when many mortgages (and other consumer loan contracts) had a prepayment penalty. That is, the lender could assess a fee if the borrower repaid the loan before the terminal date of the contract. Presentday mortgage contracts typically stipulate that there is no penalty for paying the loan off before its maturity date.

\section{Types of Mortgages}

There are a number of different types of mortgages, but the most common are the fixed-rate mortgage and the adjustable-rate mortgage (or ARM). Other types tend to be combinations of 


\section{Figure 1}

\section{Market Share of Fixed-Rate Mortgages and Contract Interest Rate}

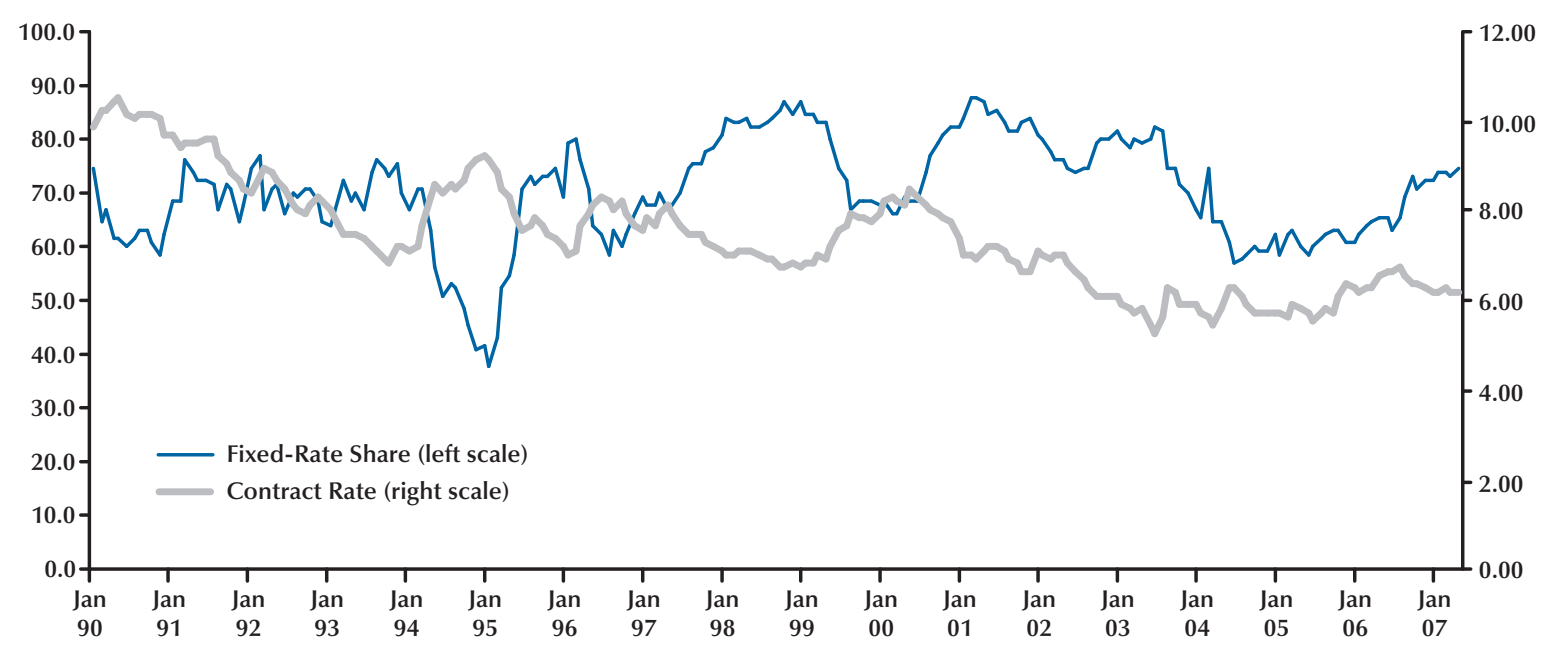

these two. Fixed-rate mortgages are by far the most common type of mortgage, accounting for about 70 percent of the total mortgage market. Figure 1 shows the percentage of the total mortgage market accounted for by 15- and 30-year fixed-rate mortgages since 1990 as well as the average contract interest rate. One would expect that lower contract interest rates would lead to a higher percentage of fixed-rate mortgages, as borrowers try to lock in low rates. This relationship seems to hold true over most of the period, but breaks down after 2002. The benefits of a fixedrate mortgage are as follows: (i) the monthly payment (interest and principal) is constant for the term of the mortgage and (ii), regardless of the behavior of market interest rates, the interest rate paid by the borrower is the same for the life of the loan.

ARMs, however, have interest rates that vary over the term of the loan in step with some index. The two most common indices are the Eleventh Federal Home Loan Bank Board District Cost of Funds Index (COFI) and the National Cost of Funds Index. ARMs have various features depending on the mortgage broker. Most often, an introductory rate is fixed for a period of time ranging from 2 to 5 years. Following this period, the interest rate will rise or fall with the index (plus a fixed markup called the margin) at some specified time interval, generally every six months. Typically, the amount that the interest rate can rise or fall in a particular interval is limited and upper and lower bounds for the interest rate over the life of the loan are set.

Rates on ARMs are lower than on otherwise equivalent fixed-rate mortgages. The reason is that the borrower is bearing some of the market risk. Market risk arises because of the inverse (or negative) relationship between interest rates and bond prices. Specifically, if the market interest rate rises, the value of the bond (mortgage) falls and vice versa. For example, consider the effect of an increase in the market interest rate on the market value of a 30-year, $\$ 200,000,5$ percent fixed-rate mortgage. The price of the 30-year mortgage decreases by $\$ 20,925.31$ (from $\$ 200,000$ to $\$ 179,074.69)$ if the market interest rate rises from 5 percent to 6 percent. If the holder of the mortgage were to sell it, they would suffer what is referred to as a capital loss. Moreover, the price of a longer-term mortgage falls by more than the price of a shorter-term mortgage for a given increase in market interest rates. For example, the 


\section{Table 1}

\section{Comparing Effective Interest Rates on Fixed- and Adjustable-Rate Mortgages (assuming an LTV ratio between 0.8 and 0.9 )}

\begin{tabular}{lclc} 
& Fixed-rate & ARM & Difference \\
\hline 1997 & 7.91 & 6.95 & 0.96 \\
1998 & 7.21 & 6.69 & 0.52 \\
1999 & 7.47 & 6.93 & 0.54 \\
2000 & 8.3 & 7.5 & 0.8 \\
2001 & 7.19 & 6.72 & 0.47 \\
2002 & 6.84 & 6.13 & 0.71 \\
2003 & 6.05 & 5.2 & 0.85
\end{tabular}

SOURCE: Federal Housing Finance Board, historical summary tables, by loan to price ratio; www.fhfb.gov/Default.aspx?Page=53.

price of a 5-year mortgage would have decreased by just $\$ 4,774.97$ (from $\$ 200,000$ to $\$ 195,225.03$ ) with the same increase in the interest rate (from 5 percent to 6 percent). Because mortgages have maturities that are relatively long-up to 30 years, they have a relatively high degree of market risk.

Of course, the reverse is also true. If the market interest rate were to fall, the value of the mortgage would rise and the holder of the mortgage would realize a capital gain. The problem is that interest rates are extremely difficult to predict. If the markets were populated by investors who are indifferent to whether they sustain a capital loss or a capital gain (i.e., indifferent to risk), the fact that bond prices and interest rates are inversely related would not be an issue. Interest rates would be invariant to the maturity of the asset. However, financial markets are populated by risk-adverse lenders (i.e., those more concerned with suffering a capital loss than a getting a capital gain). Consequently, there is a risk premium on bonds (including mortgages) that increases as the term of the loan increases. The risk premium is tiny-essentially zero-for loans of only a few months. The risk premium for 30-year loans can be fairly large, depending on market circumstances.

Because the interest rates on ARMs adjust over the term of the loan, ARMs have less market risk than the corresponding fixed-rate loan with the same maturity. Consequently, with an ARM, some of the market risk associated with mortgage lending is assumed by the borrower. As noted earlier, like anything else, risk is priced. Hence, ARMs have an initial rate that is lower than the rate on an otherwise equivalent-maturity fixedrate loan. Table 1 shows the annual average difference between the initial rates on conforming fixed-rate mortgages and ARMs from 1997 to 2004. The differences vary from year to year, but range from about 50 to about 100 basis points. ${ }^{4}$ Because ARMs have a lower initial interest rate, they are particularly good for individuals who plan either to sell their house or pay off the loan after a short period of time.

\section{THE MORTGAGE MARKET}

The mortgage market is a phrase that describes a vast array of institutions and individuals who are involved with mortgage finance in one way or another. This market is broken down into two separate yet connected entities: the primary mortgage market and the secondary mortgage market. The primary mortgage market is a market where new mortgages are originated. The secondary mortgage market is a market where existing mortgages are bought and sold. Historically, the secondary mortgage market was small and relatively inactive. Two entities, the Federal National

\footnotetext{
4 One basis point is one one-hundredth of a percentage point.
} 


\section{Figure 2}

\section{Secondary Market Activity of Total Mortgage Loans}

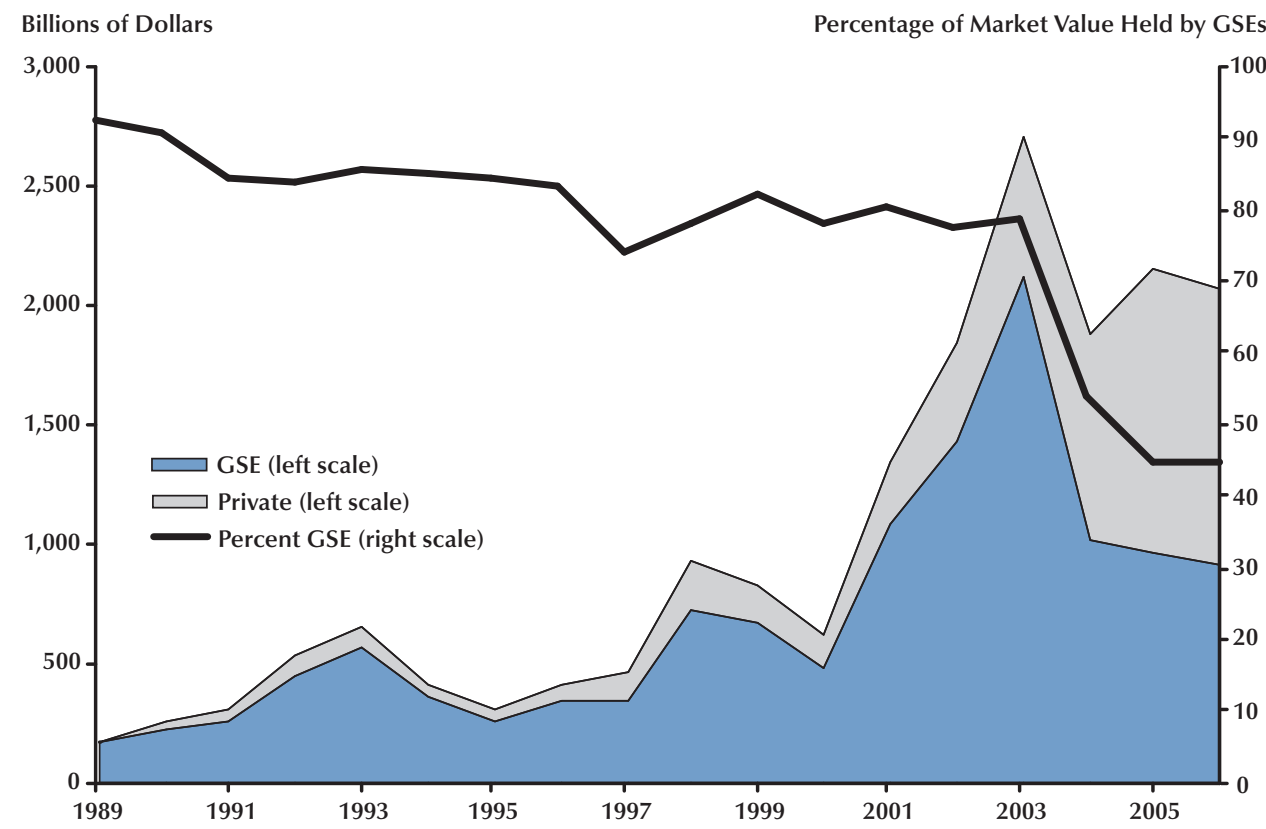

Mortgage Association (Fannie Mae) and the Federal Home Loan Mortgage Corporation (Freddie Mac), have changed that. ${ }^{5}$ These firms were chartered by Congress to create a secondary market in residential mortgages. They are private companies and not part of the U.S. government; however, they are called government-sponsored enterprises (GSEs) because the government places looser restrictions on them relative to fully private companies. Specifically, Fannie Mae and Freddie Mac are exempt from state and local taxes (except property taxes) and have conditional access to a $\$ 2.25$ billion line of credit from the U.S. Treasury.

Fannie Mae and Freddie Mac issue debt and use the proceeds from the sale of their debt to purchase mortgages in the secondary market. Although the debt that they issue is not backed by the full faith and credit of the United States government-i.e., is not explicitly government

5 For a more detailed discussion of the evolution of the secondary mortgage market, see Gerardi, Rosen, and Willen (2007), Frame and White (2005), and Green and Wachter (2005).
debt-GSE debt typically trades at interest rates only a few basis points more than that of otherwise equivalent government debt. This suggests that investors believe that the United States government would honor GSE debt in the event of a crisis.

Because of Fannie Mae and Freddie Mac and the increased sophistication of U.S. financial markets more generally, the secondary market in residential mortgages expanded rapidly in the 1990s and now plays a major role in residential finance. Figure 2 shows the growth of the secondary mortgage market since 1989 on the left axis. The right axis displays the percentage of secondary market value created by GSEs. Although the GSEs account for much of the secondary mortgage market growth in the late 20th century, their influence has decreased sharply in recent years as more and more private firms have entered the market. Before the growth of the secondary mortgage market, banks and savings and loan associations made most of the residential real estate loans. 
Most often, they originated the loan, serviced the loan contract, and actually lent the money. The growth of the secondary market has resulted in increased specialization in mortgage finance. It is now frequently the case that the originator of the loan does not hold it until maturity. They take applications and do all of the necessary credit checks and paper work until the time that the loan is closed (i.e., the loan agreement is signed). In many cases the mortgage originator initially makes the loan; however, their intention is to sell the loan quickly. Such firms generate earnings from the fees they charge. The individual or entity that purchases the mortgage is actually making the loan. It is also the case that the entity that makes the loan does not necessarily service the loan contract-that is, collect the periodic interest and principal payments, notify the borrower of overdue payments, keep records, and make property tax and homeowner's insurance payments. Instead, other firms charge a fee for providing these services. In some cases, loans are sold individually, while in other cases they are packaged together and sold as a single asset. The practice of consolidating loans or other debt instruments into single assets or securities is called securitization. Securitization is now common in the mortgage market. Mortgage-backed securities, as these assets are called, are bought and sold in financial markets much like stocks or IOUs from private companies or the government: for example, corporate bonds, government Treasury bills and bonds, commercial paper, and negotiable certificates of deposit.

To limit the risk of default, Fannie Mae and Freddie Mac place restrictions on the mortgage debt that they will purchase. Factors that play an important role in assessing the risk of a particular loan are as follows: the payment-to-income ratio, the debt-to-income ratio, the loan-to-value ratio, and the size of the loan. The payment-to-income ratio is the monthly loan payment including real estate taxes divided by the borrower's monthly income. The debt-to-income ratio is the ratio of all monthly debt expenses to monthly gross income. The loan-to-value, or LTV, ratio is the loan amount divided by the estimated (or appraised) value of the property where the difference between the estimated property value and the loan amount is the down payment.

There are no hard and fast rules about limits to these ratios because other factors, such as an individual's credit history, enter in to the determination of an individual's creditworthiness; however, there are some guidelines. Traditionally, a payment-to-income ratio much larger than 25 percent or a debt-to-income ratio of more than about 36 percent is considered cause for concern. A loan is considered "conventional" or "conforming" if the LTV ratio is 80 percent or smaller. As a general rule, the higher these ratios are, the greater is the risk of default. Loans made to borrowers that have ratios significantly larger than those stated above or other impairments, such as low credit scores, are considered subprime. ${ }^{6}$

Fannie Mae and Freddie Mac do not purchase loans that exceed a certain amount. The maximum loan amount changes yearly based on the results of a survey by the Federal Housing Finance Board. For a one-family home in the lower forty-eight states in 2007, the maximum loan amount is $\$ 417,000$. Loans larger than this amount are referred to as jumbo loans. Taken together, these guidelines and requirements give lenders an idea of the level of risk that the secondary market is willing to bear.

Like anything else, risk has a price. Lenders compensate for making higher-risk loans by charging a higher interest rate. There are a number of ways this can be done. The most obvious is that the lender merely charges a higher interest rate on more-risky mortgage loans-the greater the risk of default, the higher the rate. Hence, it is not surprising that on average subprime loans have a higher stated interest rate than conventional loans. There are other ways to charge a higher effective rate, however. For example, in the case of an LTV ratio that is greater than 80 percent, the lender often requires the borrower to purchase private mortgage insurance (PMI), whereby a third party bears the risk of default. The borrower may prefer this option to paying a higher mortgage rate because once the LTV ratio reaches 80 percent (either by an appreciation of the property value

\footnotetext{
${ }^{6}$ For more details, see Chomsisengphet and Pennington-Cross (2006).
} 
or a reduction in the loan balance over time), the PMI can be discontinued.

The lender is also protected if the borrower achieves an LTV ratio of 80 percent by taking a second mortgage to make up the difference. For example, the borrower may have an 80-10-10 mortgage, indicating that 80 percent of the loan is financed by the first mortgage, 10 percent is financed by a second mortgage, and 10 percent is a down payment. Even smaller down payments, including no down payment at all, are possible. Such loans are frequently, but not always, subprime. Because the second mortgage is subordinate to the first-meaning that in the case of default, it is repaid only after the first mortgage is repaid - the holder of the second mortgage bears most of the default risk. Consequently, the interest rate on the second mortgage is higher than that on the first. Borrowers may benefit from using this method, however, because the second mortgage typically has a shorter maturity than the first. Hence, once the second mortgage is paid off, the borrower has only the lower-interest first mortgage. In any event, borrowers with LTV ratios greater than 80 percent can expect to pay more either by paying a higher rate on the first mortgage, by taking out PMI, or by having a higherinterest second mortgage. Mortgage borrowers with LTV ratios less than 80 percent do not, however, typically receive significantly lower interest rates. The reason is that the default risk is very small when the LTV ratio is 80 percent. Lenders know that with this LTV ratio, it is very likely that they will be able to recover all or nearly all of the loan balance in the event of a default. Consequently, a smaller LTV ratio provides essentially no reduction in default risk; hence, there is no reason for the lender to compensate the borrower by giving the borrower a lower interest rate.

The existence of a secondary mortgage market is beneficial to both the borrower and the lender. For the borrower, robust mortgage trading allows for more intense competition; 20 or 30 years ago, local financial institutions were the only option for some borrowers. Today, borrowers have access to national (and even international) sources of mortgage finance. Additionally, the Internet has provided an outlet to quickly compare mortgage rates. Investors also benefit by having a wider range of investments that they can use to diversify their portfolio. Moreover, a well-functioning secondary mortgage market allows investors to realign their portfolios as circumstances change.

\section{MORTGAGE FINANCE}

Now that we have discussed some facts about mortgages and the mortgage market, it is time to discuss the nuts and bolts of mortgage payment schedules and the real effective interest rate that one pays when taking out a mortgage. We begin our discussion by showing how the fixed, monthly payment on a fixed-rate mortgage is determined. To make the discussion as concrete as possible, we consider a borrower who wants a $\$ 200,000$, 30 -year, fixed-rate mortgage with a contract interest rate of 6 percent annually. The question is how much will this borrower have to pay each month to pay off the loan in 30 years? The answer, $\$ 1,199.10$, is obtained from the formula

$$
M P=M B_{0}(1+r)^{n} \frac{r}{(1+r)^{n}-1},
$$

where $M P$ is the monthly mortgage payment, $M B_{0}$ is the initial mortgage balance-the amount borrowed $-n$ is the number of months over which the loan is amortized, and $r$ is the monthly interest rate (annual interest rate divided by twelve). Consequently, the monthly payment is

$$
\begin{aligned}
& M P= \\
& \$ 200,000(1+0.06 / 12)^{360}\left[\frac{0.06 / 12}{(1+0.06 / 12)^{360}-1}\right]=\$ 1,199.10 .
\end{aligned}
$$

This formula may seem complicated, but it has an intuitive explanation. The first part of the formula, $M B_{0}(1+r)^{n}$, is just the total outstanding balance if someone borrowed $\$ 200,000$ and made no payments for 30 years. It demonstrates the effect of what is called compound interest-that is, accumulating interest on both the principal and the interest in the previous month every month for 30 years. To illustrate, assume that no payment is made during the first month. The outstanding balance at the end of the first month, 
$M B_{1}$, would be $\$ 201,000=\$ 200,000+\$ 200,000$ (0.005), i.e., $M B_{1}=M B_{0}+r M B_{0}$. Note that this expression can be rewritten more compactly as $M B_{1}=M B_{0}(1+r)$, i.e., $\$ 200,000(1.005)=\$ 201,000$. If no payment were made the next month, by the end of the second month the total amount owed, $M B_{2}$, would be $\$ 201,000+\$ 201,000(0.005)=$ $\$ 201,000(1.005)=\$ 202,005$ - the amount of the initial loan, plus $\$ 1,000$ in interest for the first month and \$1,005 in interest the second month. Note that the additional $\$ 5$ for the second month is interest paid on the $\$ 1,000$ in interest owed at the end of the first month-earning interest on interest, i.e., "compound interest." Also, note that the amount owed at the end of the second month could be written more compactly as $\$ 200,000$ $(1.005)^{2}=\$ 202,005$, i.e., $M B_{2}=M B_{1}(1+r)=$ $M B_{0}(1+r)(1+r)=M B_{0}(1+r)^{2}$. This process generalizes to any number of months so that

$$
M B_{m}=M B_{0}(1+r)^{m} .
$$

Equation (2) is the equation for compound interest. In the case of our 30-year mortgage example, if no payments were made for the life of the loan, the balance at the end of 30 years would be $\$ 200,000(1.005)^{360}=\$ 1,204,515.04$.

The second part of the monthly payment equation, $r /\left[(1+r)^{n}-1\right]$, aggregates the effects of monthly interest and principal payments. It reflects the fact that rather than letting the interest accumulate over time, the fixed monthly payment covers all of the interest accrued during the month and pays off part of the principal. Instead of owing $\$ 201,000$ at the end of the first month of the mortgage if no monthly payment were made, the individual who makes monthly payments would owe $\$ 199,800.90=\$ 201,000-\$ 1,199.10$. Each successive month, more of the fixed monthly payment goes to principal and less goes to interest as the principal balance declines. An amortization schedule for our hypothetical loan is presented in Table 2. Notice that it takes a long time to repay the principal. After 10 years of the 30 -year mortgage, only about 16 percent of the principal has been repaid. It takes 21 years before half of the principal has been repaid.

\section{Annual Percentage Rate}

The analysis above is based on the contract rate on the mortgage. The effective rate on the mortgage can be higher-in some cases, considerably higher. The purpose of this section is to discuss the factors that affect the effective rate that is paid on a mortgage. To help borrowers compare the cost of borrowing, the Truth in Lending Act requires that lenders disclose the annual percentage rate, or APR. The Federal Truth in Lending Act was contained in the Consumer Credit Protection Act of 1968. This act is implemented by the Board of Governors of the Federal Reserve System with Regulation Z. Among other things, Regulation Z requires that all lenders disclose the APR on credit to potential borrowers. The purpose of the APR is to make the interest costs of loans with different structures, fees, etc., comparable. However, because loans can differ in many ways, the stated APR may not reflect the actual interest rate paid by the borrower. We begin by discussing the rationale for the APR and its calculation. We then discuss reasons and situations where the stated APR will not reflect the true interest rate paid by the borrower.

Calculating the APR. To understand the calculation of the APR, it is necessary to show how to determine the current price of any asset. Basically, the value of any asset is equal to the present value of the income it generates over time. The idea of present value is closely related to the idea of compound interest covered here previously. Compound interest answers the question: If I invest a sum of money (say $\$ 200,000$ ) today, how much will I have at some future date (say 30 years from now) if the annual interest rate is $r$ percent (say 6 percent)? In our mortgage example, the question was fundamentally the same-if I borrow $\$ 200,000$ today at an interest rate of 6 percent, how much will I owe in 30 years if I make no monthly payments? Our answer was $\$ 1,204,515.04$.

Present value asks the reverse question: If I am to get a sum of money (say $\$ 1,204,515.04$ ) at some future date (say 30 years from now), how much would it be worth to me today if the annual interest rate is 6 percent? Now of course the answer is $\$ 200,000$. Hence, the present value 


\section{Table 2}

Partial Amortization Table for a 6 Percent Fixed-Rate Mortgage

\begin{tabular}{|c|c|c|c|c|c|}
\hline Month & $\begin{array}{c}\text { Beginning } \\
\text { mortgage balance }\end{array}$ & $\begin{array}{l}\text { Monthly } \\
\text { payment }\end{array}$ & $\begin{array}{c}\text { Interest } \\
\text { for month }\end{array}$ & $\begin{array}{l}\text { Principal } \\
\text { repayment }\end{array}$ & $\begin{array}{c}\text { Ending } \\
\text { mortgage balance }\end{array}$ \\
\hline 1 & $\$ 200,000.00$ & $\$ 1,199.10$ & $\$ 1,000.00$ & $\$ 199.10$ & $\$ 199,800.90$ \\
\hline 2 & $199,800.90$ & 1,199.10 & 999.00 & 200.10 & $199,600.80$ \\
\hline 3 & $199,600.80$ & $1,199.10$ & 998.00 & 201.10 & $199,399.71$ \\
\hline 4 & $199,399.71$ & 1,199.10 & 997.00 & 202.10 & $199,197.60$ \\
\hline 5 & $199,197.60$ & 1,199.10 & 995.99 & 203.11 & $198,994.49$ \\
\hline 6 & $198,994.49$ & 1,199.10 & 994.97 & 204.13 & $198,790.36$ \\
\hline 7 & $198,790.36$ & 1,199.10 & 993.95 & 205.15 & $198,585.21$ \\
\hline 8 & $198,585.21$ & $1,199.10$ & 992.93 & 206.17 & $198,379.04$ \\
\hline 9 & $198,379.04$ & $1,199.10$ & 991.90 & 207.21 & $198,171.83$ \\
\hline 10 & $198,171.83$ & $1,199.10$ & 990.86 & 208.24 & $197,963.59$ \\
\hline 11 & $197,963.59$ & $1,199.10$ & 989.82 & 209.28 & $197,754.31$ \\
\hline 12 & $197,754.31$ & $1,199.10$ & 988.77 & 210.33 & $197,543.98$ \\
\hline 35 & $192,641.11$ & $1,199.10$ & 963.21 & 235.90 & $192,405.22$ \\
\hline 36 & $192,405.22$ & 1,199.10 & 962.03 & 237.07 & $192,168.14$ \\
\hline 59 & $186,641.83$ & $1,199.10$ & 933.21 & 265.89 & $186,375.94$ \\
\hline 60 & $186,375.94$ & 1,199.10 & 931.88 & 267.22 & $186,108.71$ \\
\hline 118 & $168,447.40$ & 1,199.10 & 842.24 & 356.86 & $168,090.54$ \\
\hline 119 & $168,090.54$ & 1,199.10 & 840.45 & 358.65 & $167,731.89$ \\
\hline 120 & $167,731.89$ & $1,199.10$ & 838.66 & 360.44 & $167,371.45$ \\
\hline 121 & $167,371.45$ & $1,199.10$ & 836.86 & 362.24 & $167,009.21$ \\
\hline 122 & $167,009.21$ & $1,199.10$ & 835.05 & 364.06 & $166,645.15$ \\
\hline 238 & $109,964.76$ & $1,199.10$ & 549.82 & 649.28 & $109,315.48$ \\
\hline 239 & $109,315.48$ & 1,199.10 & 546.58 & 652.52 & $108,662.96$ \\
\hline 240 & $108,662.96$ & $1,199.10$ & 543.31 & 655.79 & $108,007.17$ \\
\hline 241 & $108,007.17$ & $1,199.10$ & 540.04 & 659.07 & $107,348.11$ \\
\hline 242 & $107,348.11$ & 1,199.10 & 536.74 & 662.36 & $106,685.75$ \\
\hline 251 & $101,266.24$ & $1,199.10$ & 506.33 & 692.77 & $100,573.47$ \\
\hline 252 & $100,573.47$ & $1,199.10$ & 502.87 & 696.23 & $99,877.23$ \\
\hline 253 & $99,877.23$ & 1,199.10 & 499.39 & 699.71 & $99,177.52$ \\
\hline 254 & $99,177.52$ & 1,199.10 & 495.89 & 703.21 & $98,474.30$ \\
\hline 355 & $7,070.36$ & $1,199.10$ & 35.35 & $1,163.75$ & $5,906.61$ \\
\hline 356 & $5,906.61$ & $1,199.10$ & 29.53 & $1,169.57$ & $4,737.04$ \\
\hline 357 & $4,737.04$ & $1,199.10$ & 23.69 & $1,175.42$ & $3,561.63$ \\
\hline 358 & $3,561.63$ & $1,199.10$ & 17.81 & $1,181.29$ & $2,380.33$ \\
\hline 359 & $2,380.33$ & $1,199.10$ & 11.90 & $1,187.20$ & $1,193.14$ \\
\hline 360 & $1,193.14$ & $1,199.10$ & 5.97 & $1,193.14$ & 0.00 \\
\hline
\end{tabular}


formula is just the inverse of the compound interest formula, i.e.,

$$
M B_{0}=M B_{m} /(1+r)^{m} .
$$

In the case of mortgages, and most investments, all of the money is not paid on the maturity date. Rather, income is received periodically over time. The present value of the entire stream of income to be received over time is just the sum of the present value of each of the future payments. In the case of our mortgage example, the present value of the mortgage loan is given by

$$
M B_{0}=\frac{M P_{1}}{(1+r)^{1}}+\frac{M P_{2}}{(1+r)^{2}}+\cdots+\frac{M P_{360}}{(1+r)^{360}},
$$

where $M P_{i}$ denotes the monthly payment to be received $i$ months in the future. In the case of a fixed-rate loan, the monthly payments are the same-that is, $M P_{i}=M P_{j}$ for all $i$ and $j$-and equation (4) can be written more compactly as

$$
M B_{0}=M P\left(\frac{(1+r)^{m}-1}{r(1+r)^{m}}\right) .
$$

For our hypothetical mortgage, the present value of receiving $\$ 1,199.10$ per month for 30 years is

$$
\$ 1199.10\left(\frac{(1.005)^{360}-1}{0.005(1.005)^{360}}\right)=\$ 200,000 .
$$

This shows that the mortgage lender is, in essence, purchasing an investment that pays $\$ 1,199.10$ per month for each of the next 360 months.

In this example, we knew $M P$ and $r$, so we could solve the equation for the present value, $M P_{0}$. Although it is more complicated to solve, if we knew $M P$ and $M P_{0}$ we could have solved the equation for $r$. The question is, If I were to pay $\$ 200,000$ today for the right to receive $\$ 1,199.10$ each month for the next 360 months, what would be the effective annual interest rate? Of course, we know the answer is 6 percent (0.005 times 12).

Equation (5) can be modified slightly to determine the APR. The modification stems from the fact that there are expenses associated with financing the purchase of a home rather than paying cash for it. These additional expenses are considered pre-paid interest. For example, if you borrow $\$ 200,000$ to buy a home but, in doing so, incur $\$ 3,000$ in expenses solely because you are financing the purchase, you are in effect only borrowing $\$ 197,000$. The calculation of the APR accounts for this fact by making an adjustment for these expenses, which are referred to as fees. Hence, the APR is the interest rate that solves

$$
M B_{0}-\text { Fees }=M P\left(\frac{(1+r)^{m}-1}{r(1+r)^{m}}\right) .
$$

So, applying this formula to our hypothetical example, solving the equation

$$
\$ 200,000-\$ 3,000=\$ 1,199.10\left(\frac{(1+r)^{360}-1}{r(1+r)^{360}}\right)
$$

for $r$, yields a monthly interest rate of 0.512 percent or an annual APR of 6.142 percent.

Obviously, the larger are the fees, the smaller is the effective loan and the higher is the APR. Hence, when considering a mortgage, one must consider both the stated mortgage rate and the fees that are required to get this rate. Indeed, it is often possible to get a lower mortgage rate by paying higher fees. When considering such options, the APR can be very useful for deciding which mortgage option is best.

It is important to note that the APR is not always calculated the same way by all financial institutions; different fees may or may not be included. According to the Federal Reserve Board, fees that are considered part of the finance charge are as follows: interest, service charges, buyer's points, assumption fees, and insurance charges required by the lender (with a few exceptions). Fees that are not part of the finance charge are application fees (if charged to all applicants), late fees, bounced check fees, seller's points, titling fees, appraisals, credit report fees, taxes, notary fees, and fees for opening an escrow account. ${ }^{7}$

\footnotetext{
7 The general rule is that if the fee is charged solely because the purchase is being financed, it should be included. Excluding credit report fees would appear to violate this rule because they are included solely because the purchase is being financed. Congress wrote this exclusion into the Truth in Lending Act.
} 


\section{Table 3}

\section{Fees and the Annual Percentage Rate}

\begin{tabular}{|c|c|c|}
\hline Included & Excluded & Sometimes included \\
\hline Interest & Late payment fees & Appraisals (excluded if required of all applicants) \\
\hline Service or carrying charges & Returned check fees & $\begin{array}{l}\text { Home inspections and pest inspections } \\
\text { (excluded if required of all applicants) }\end{array}$ \\
\hline Broker fees & Title fees & Voluntary insurance \\
\hline Private mortgage insurance & Taxes & $\begin{array}{l}\text { Application fees (excluded if required of all } \\
\text { applicants, otherwise included) }\end{array}$ \\
\hline Assumption fees & License fees & \\
\hline Points & Appraisal fees & \\
\hline $\begin{array}{l}\text { Fees for establishing an } \\
\text { escrow account }\end{array}$ & Credit report fees & \\
\hline
\end{tabular}

Table 3 displays the fees that are included and excluded from the APR. The third column displays fees which may or may not be included, depending on the lender and the size of the fee.

It is also important to note that the lender has some leeway in terms of the accuracy of the APR that he reports. The actual finance charge can be underreported by as much as $\$ 100$. Also, according to Regulation Z, the reported rate is considered accurate if it is within one-eighth of 1 percent of the true rate. If one bank quotes a rate of 6.125 percent while another bank quotes a rate of 6.25 percent, it is hard to determine which rate is really lower because of the allowed margin of error.

Value of the APR. The APR is very useful, but it has limitations. Important among these is the fact that the APR assumes that you will have the mortgage for its entire term. Although most mortgages have a term of 30 years, only a small portion of mortgages last their full term. Most mortgages are paid off early, because the borrower prepays the loan, sells the property, refinances the mortgage, or defaults. According to Douglas Duncan, chief economist of the Mortgage Bankers Association, the average term of a mortgage is 3 to 5 years. The APR for our previous hypothetical \$200,000, 30-year mortgage-assuming closing costs of $\$ 3,000$-is 6.142 percent. This APR is based on the assumption that this mortgage will run to term (i.e., 30 years). But if the house is sold or the mortgage refinanced after 3 years, the effective APR would be 6.577 percent. If it is sold or refinanced after 5 years, the effective APR would be 6.367 percent. A modification to our original formula is necessary to calculate the APR of a loan that is paid off before maturity. The modification comes from the fact that rather than paying off the entire loan over the term of the mortgage, the borrower must pay off the remainder of the mortgage balance, $R B_{m}$, when the loan is repaid. The modification takes the present value of this payment into consideration in calculating the APR. Specifically, the modified APR formula is

(7) $M B_{0}-$ Fees $=M P\left(\frac{(1+r)^{m}-1}{r(1+r)^{m}}\right)+\frac{R B_{m}}{(1+r)^{m}}$.

The remaining balance on our mortgage can be read off the corresponding row of our amortization table (Table 2). After 5 years, the remaining mortgage balance is $\$ 186,375.94$ (the balance at the end of 59 months or the beginning of 60 months). Applying the formula to our example,

$$
\begin{aligned}
& \$ 200,000-\$ 3,000= \\
& \$ 1,199.10\left(\frac{(1+r)^{59}-1}{r(1+r)^{59}}\right)+\frac{\$ 186,375.94}{(1+r)^{59}} ;
\end{aligned}
$$


solving for $r$ gives a monthly interest rate of 0.531 percent, or an annual rate of 6.367 percent. Hence, the quoted APR understates the true effective interest rate if the borrower plans to prepay the loan before its maturity date.

The APR is also less useful for comparing ARMs. The quoted APR on an ARM is not only based on the full term of the loan, but also assumes that the index to which future rate adjustments are linked will remain constant for the life of the loan. It neither accounts for the volatility of the index nor allows borrowers to compare the different indices that may be available. It also ignores the maximum rates allowed under a particular adjustable rate structure.

\section{Refinancing}

There are three reasons that someone might want to refinance a mortgage: to obtain a lower interest rate, to consolidate interest payments that are not tax deductible into mortgage interest payments which are tax deductible, or to obtain cash for some other purpose. Refinancing to lower interest payments is often a good idea if interest rates have fallen since the original mortgage closed or if a person currently has an ARM and wants to avoid the uncertainty of future interest rate adjustments. There are two important facts to keep in mind when considering refinancing solely to obtain a lower interest rate. The first is the term of the loan. If the new mortgage has a term that is shorter than the term remaining on the existing mortgage, the only issue is whether the effective interest rate is lower than that on the current fixed-rate mortgage. If the term on the new mortgage is longer than the remaining term of the exiting mortgage, the decision is more complicated. For example, if one refinances a 30 -year mortgage with a remaining term of 20 years with a new 30-year fixed-rate mortgage, at a lower interest rate, the interest rate savings may be offset by the fact that interest will be paid over 30 years instead of 20. Of course, if the loan has no prepayment penalty, the effective term of any mortgage can be set anywhere the borrower desires simply by adjusting the payment to that of the desired term. For example, assume that after 10 years we want to refinance our current
$\$ 200,000$, 30-year mortgage that we took out when interest rates were 6 percent with a new 30-year fixed-rate mortgage with a 5 percent rate. The amortization table (Table 2) shows that the remaining balance on the loan is $\$ 167,371.45$. Using equation (1) we calculate that our monthly payment for borrowing $\$ 167,371.45$ for 30 years is $\$ 898.49$, which is $\$ 300.62$ less than the current monthly payment of $\$ 1,199.10$. While the interest rate is lower, the total interest cost over the life of the loan is $\$ 156,083.56$, compared with $\$ 120,412.80$ for a 20 -year fixed-rate mortgage at 6 percent (the current mortgage). The difference is due to the fact that interest is being paid over 30 years with the new mortgage and only 20 years with the old. Hence, while the annual interest rate is lower, the total interest cost over the life of the loan is higher.

Because there are no prepayment penalties, the borrower can effectively determine the term of the mortgage simply by adjusting the monthly payment. For example, using equation (1) we find that the monthly payment on a 20 -year, fixed-rate loan with an annual rate of 5 percent is $\$ 1,104.58$. Hence, with a monthly payment of $\$ 1,104.58$, the 30 -year loan would be paid off at the same time that the existing loan would have been paid off (20 years), with a total interest cost of $\$ 97,727.15$. Alternatively, one could maintain the monthly payment at the level of the old mortgage, $\$ 1,199.10$. In this case, the loan would be paid off in about 17 years, 6 months, with a total interest cost of about $\$ 84,000 .^{8}$

Some financial institutions offer a no-cost refinance. This means that there are no costs to the loan. In this case, the stated rate and the APR are identical. In effect, the costs are covered in the interest rate: That is, the costs have been financed, resulting in a contract interest rate that is higher than the rate for loans that have finance costs.

Comparisons such as the above are particularly important when considering consolidating non-tax-deductible debt (e.g., credit card debt and auto loans) into a mortgage. The mortgage has two advantages: the interest rate will likely

\footnotetext{
8 Note that if $M B_{0}, M P$, and $r$ are known, it is possible to solve equation (5) for $m$.
} 
be lower and the interest is deductible for tax purposes. However, if one anticipated paying off the consolidated loan before the term of the new mortgage, the interest costs could be higher because the loan is being repaid over a much longer period.

\section{Home Equity Loans}

The equity in a home is the difference between the current market value of the home and the remaining balance on all of its mortgages. Of course, the true market value of the home is not known until the house is actually sold; consequently, the home's equity is estimated by subtracting the principal remaining on existing mortgages from an estimate of the property's market value. A home equity loan is simply money borrowed using the equity in the home as collateral. Home equity loans have two advantages: First, because the loan is collateralized by the home, the interest rate is lower than what could be obtained on an otherwise identical unsecured loan. Second, with some exceptions, the interest paid on home equity loans is deductible for tax purposes. Hence, home equity loans (or home equity lines of credit) are low-cost methods of finance for many homeowners. For many people, the equity in their home is their major source of wealth. Hence, using home equity loans to finance current consumption may put their wealth at risk.

A reverse mortgage can be thought of as a particular type of home equity loan, because in this case the individual is borrowing money using the equity in the home as collateral. Instead of making payments, the homeowner receives payments. The homeowner can select to have a fixed monthly payment, a line of credit, or both. The amount owed increases with the payments or draws on the line of credit, and interest cost is based on the outstanding loan balance.

From the point of view of the lender, reverse mortgages are investments. Instead of receiving monthly payments to cover interest, fees, and principal, all of the money lent, interest payments, and incurred fees are received in a single payment when the house is sold.

Reverse mortgage loans are available only to individuals who are 62 years or older. The loan payments are not taxable and generally do not affect Social Security or Medicare benefits. Like other mortgages, lenders charge origination fees and other closing costs; consequently, the effective interest rate will be higher than the contract rate. As is the case for regular mortgages, this means that the effective interest rate may be considerably higher for individuals who stay in their homes for only a short time after taking out a reverse mortgage. Lenders may also charge servicing fees during the life of the mortgage. As with regular mortgages, the interest rate can either be fixed or variable, with the variable rate tied to a specific index that fluctuates with market rates. Reverse mortgages may be useful for people with home equity but relatively low periodic income. Because the loan is repaid when the home is sold, the danger is that the borrower will use up all of the equity in the home, having nothing to leave to their heirs. Most reverse mortgages have a "nonrecourse" clause, which prevents the borrower, or their estate, from owing more than the value of the home when it is sold. This protects the borrower, but it also means that the lender will be conservative in determining how much they are willing to lend. There are basically two types of reverse mortgages: (i) federally insured reverse mortgages known as home equity conversion mortgages (HECMs), which are backed by the U.S. Department of Housing and Urban Development (HUD), and (ii) proprietary reserve mortgages, which are privately funded.

As with any mortgage, care must be exercised when considering the costs and benefits of a reverse mortgage. To better understand reverse mortgages, it is useful to consider a hypothetical example of how a reverse mortgage works. Assume the homeowner would like to receive a monthly payment of $\$ 1,000$ and that they can obtain a reverse mortgage at an annual interest rate of 6 percent. At the end of the first month, the homeowner would owe $\$ 1,005$, the $\$ 1,000$ payment received at the beginning of the month plus $\$ 5$ interest for the month. Letting $L B_{i}$ denote the loan balance at the end of the $i$ th month, the amount owed at the end of the first month would be $L B_{i}=M P(1+r)$. The balance at the end of the second month would be the $\$ 1,005$ balance at 
the end of the first month, plus the interest on this amount for the month-that is, \$1,005(1.005) -plus the $\$ 1,000$ payment at the beginning of the second month plus interest-that is, $\$ 1,000$ (1.005). This can be expressed as $L B_{2}=M P(1+r)^{2}$ $+\mathrm{MP}(1+r)$. The amount at the end of the $m$ th month is given by

$$
\begin{aligned}
& L B_{m}= \\
& M P(1+r)^{m}+M P(1+r)^{m-1}+\cdots+M P(1+r),
\end{aligned}
$$

which can be written more compactly as

$$
L B_{m}=M P\left(\frac{(1+r)^{m}-1}{r}\right) .
$$

Note the similarity between this equation and the right half of equation (1). Now ask the question, What would be the outstanding balance at the end of 10 years if an individual drew $\$ 1,000$ per month and the annual interest rate charged was 6 percent? The answer is $\$ 163,879.35$ - that is,

$$
\$ 1,000\left(\frac{(1.005)^{120}-1}{0.005}\right)=\$ 163,879.35 .
$$

This means that if a homeowner had equity of $\$ 165,000$, they could draw $\$ 1,000$ per month for 10 years before the total amount of the loans plus interest essentially consumed all of the home's equity.

Of course, the question that individuals considering a reverse mortgage are most concerned about is, How much will I be able to receive each month given the value of my home? The answer is obtained by solving equation (8) for $M P$ - that is,

$$
M P=H E\left(\frac{r}{(1+r)^{m}-1}\right),
$$

where $H E$ replaces $L B_{m}$ and denotes the homeowner's equity-the maximum amount that the lender will lend on a reverse mortgage. Again, using our example, if the home equity is $\$ 165,000$ and the annual interest rate is 6 percent, equation (9) indicates that the individual could receive $\$ 1,006.84$ per month for 10 years.

Equation (9) considers only the interest costs.
It ignores loan origination fees and other closing costs, as well as servicing fees that the lender may charge. These costs and fees are treated as loans. Origination fees and closing costs are incurred at the time of the loan, whereas servicing fees may be charged in each period. Such costs reduce the equity available to make monthly payments. For example, assume that the closing costs are $\$ 1,000$. We know from our compound interest formula, equation (2), that in 10 years the total amount owed on this $\$ 1,000$ loan plus interest will be $\$ 1,819.40$. This means that only $\$ 163,180.60$ of the home's equity will be available for monthly payments. In our example, this means that monthly payment would be reduced from $\$ 1,006.84$ to $\$ 995.74$.

An important factor in determining the size of the monthly payment is the period of time over which payments are expected to be made. For example, assume the individual is 65 and expects to live in the home until age 85 . Hence, they would like to receive monthly payments for 20 years. Following up on our example, if we assume there are no closing costs, the monthly payment that would exhaust the $\$ 165,000$ in home equity in 20 years would be $\$ 357.11$. If we assume there is $\$ 1,000$ in closing costs, this amount is reduced to just $\$ 349.95$.

Generally speaking, the older you are when taking out the reverse mortgage, the more you will be able to borrow. This is due to the fact that the period over which you receive payments is likely to be shorter. Also, the higher the value of your home and the larger the equity, the more you can borrow. Your monthly payments will also be higher the lower the interest rate. Because the investor must project the home's future value, which is often difficult to do, reverse mortgages are relatively risky investments. Consequently, the interest rates on reverse mortgages are typically higher than those on otherwise equivalent mortgages.

\section{CONCLUSIONS}

This paper addresses a number of significant issues facing the prospective home buyer. For 
most people, buying a home is the largest purchase they will ever make, and a thorough understanding of the terminology and structure of the residential finance market can mean the difference between an agonizing experience and a rewarding one. Although the mortgage industry is too sophisticated to describe completely in this short paper, hopefully the concepts elucidated here will reduce the anxiety for those trying to finance the American dream.

\section{REFERENCES}

Bernanke, Ben S. "The Housing Market and Subprime Lending." Speech to the 2007 International Monetary Conference, Cape Town, South Africa, June 5, 2007; www.federalreserve.gov/boarddocs/ speeches/2007/20070605/default.htm.

Chomsisengphet, Souphala and Pennington-Cross, Anthony. "The Evolution of the Subprime Mortgage Market." Federal Reserve Bank of St. Louis Review, January/February 2006, 88(1), pp. 31-56.

Frame, W. Scott and White, Lawrence J. "Fussing and Fuming over Fannie and Freddie: How Much Smoke, How Much Fire?" Journal of Economic Perspectives, Spring 2005, 19(2), pp. 159-84.

Gerardi, Kristopher; Rosen, Harvey S. and Willen, Paul. "Do Households Benefit from Financial Deregulation and Innovation? The Case of the Mortgage Market.” CEPS Working Paper No. 141, Center for Economic Policy Studies, March 2007.

Green, Richard K. and Wachter, Susan M. "The American Mortgage in Historical and International Context." Journal of Economic Perspectives, Fall 2005, 19(4), pp. 93-114. 
